\title{
Kilounit per Kilogram
}

National Cancer Institute

\section{Source}

National Cancer Institute. Kilounit per Kilogram. NCI Thesaurus. Code C67382.

An arbitrary unit of substance content expressed in thousands of units of biological activity per unit of mass equal to one kilogram. Kilounit per kilogram is also used as a dose calculation unit expressed in thousands of arbitrary units per one kilogram of body mass. 